\title{
PROCESSING SKILLS IN SCIENCE INSTRUCTION AS A MEANS TO INCREASE ELEMENTARY SCHOOL STUDENTS' MENTAL, PHYSICAL AND SOCIAL BASIC SKILLS
}

\author{
Silvinia $^{\mathrm{a}}$ \\ ${ }^{a}$ Padang State University, Padang, Indonesia \\ Corresponding e-mail: silviniazakir090753@yahoo.com
}

\begin{abstract}
This paper aims to explain the definition of processing skills in science instruction in elementary school, the importance of processing skills, the theme on applying processing skills, the skills that usually used in science instruction (observing skills, classifying, communicating, measuring, predicting, and making conclusion) and the steps in applying processing skills. The approach of processing skills is a learning approach that aims to improve basic skills such as mental, physical and social skills to inquire fact and concept or improving behavior and norm through learning activities that able to improve students' skills. The mean of the final test on cycle I is 69 . After learning improvisation in cycle II students' score increase. The mean of the test on first meeting in cycle II is 79 and on the second meeting is 85 .
\end{abstract}

Keywords: Processing Skills, Science concept, Social, Mental, Physical

\section{INTRODUCTION}

The problems that exist in the world of formal education increase from year to year. One of the main problems faced by Indonesia is the low quality of formal education at every level of education. Efforts have been made to improve this through various training and teacher competence improvement; procurement of books and instructional tools; improvement of education facilities and infrastructure as well as improvement of school management quality. However, various indicators of education quality have not shown significant improvement. Many people have question about what is wrong in the organization of our education? From various observations and data analysis, there are many factors that cause the quality of education has not increased significantly, one of them is the approach used in the classroom has not been able to create optimal conditions for learning.

All this time, the approach used is the inputoutput analysis, which is assumes that if educational inputs such as teacher training, procurement of books and learning tools, improvement of other educational facilities and infrastructure are met then the quality of education will automatically occur. In fact, the expected quality of education does not occur because the approach is too focused on educational input and less attention to the educational process whereas this largely determines the output of education. The process of education can not be separated from the teaching and learning activities in the classroom. Those are determined by the cooperation between teachers and students. Teachers are required to be able to present the subject matter with optimum. Therefore, new creativity and ideas are needed to develop ways of presenting the subject matter in school

Creativity is teacher ability to choose the appropriate methods, approaches and media in the presentation of subject matter. The fact shows that there are still many teachers who use traditional approach in science learning so that students have not been directed to understand their own science concepts being studied. The traditional approach has not been able to develop cognitive (reasoning), affective (attitude), and psychomotor (skills) abilities as outlined in the GBPP. Thus, the students only tend to memorize the science concepts that they learn without understanding them properly. As a result, mastery of students' IPA concepts becomes very less. In addition, teachers as informants tend to dominate learning activities in the classroom so 
there is no mutual relationship between teachers and students that have implications for the quality of learning in teaching and learning process of science. From the above description, then one of the efforts considered to solve the problem is to use the process skills approach as a strategy that is expected to involve students actively in science learning.

\section{DISCUSSION}

\subsection{Definition of Process Skills Approach}

Approach of process skill is teaching and learning approach that leads to the development of basic ability in the form of physical and social mental to find facts and concepts. In other words, it means that development of attitudes and values through teaching and learning process that has enabled students so as to grow a certain number of skills in the students themselves. In the guidance of the implementation of teaching and learning process, it is also explained that what is meant by process skill. It is the student's skill to manage the learning gain obtained through teaching and learning process which gives wider opportunity to the students to observe, classify, predict, apply, plan, and communicate.

Basically, the physical and mental skills as well as the development of process skills have been owned by the child even in the form of potential or ability that is still low, the ability that still needs to be realized. According to Suryo Subroto (1995: 75), "By developing the skills of processing in the learning approach, the pupil will be able to discover and develop the attitudes and values required throughout the rhythm of motion or action in a true teaching-learning process creating conditions for active student learning."

According to Azhar in Ade Sanjaya (1993: 7), "Process skill is students' ability to manage (obtain) what is they learn in teaching and learning activities (KBM) that provide the widest opportunity for students to observe, classify, interpret, forecast, apply, plan research, communicate the results."

Thus, through the process skills approach is applied attention to enable students to learn something in realizing an interest that ultimately leads to an engagement based on a sense of responsibility in the face and solve problems in learning. The process of teaching and learning always should include students actively in order to develop students' abilities such as the ability to observe, interpret, predict, apply concepts, plan and conduct research, and communicate the findings.
In accordance with the objectives of the process skill approach are:

A) Provide motivation for students to learn because in the process skills of student are encouraged to always participate actively in learning.

B) To understand more the concept of definition and facts learned by students as essentially the students themselves who seek and find the concept.

C) To develop knowledge or theory with the reality of life in society so that between the theory and reality of life will be harmonious.

D) As preparation and practice in facing life of society because students have been trained to think logically in solving problems.

E) Develop a confident, responsible and social solidarity attitude in the face of various problems.

Basically this process skill is implemented by emphasizing on how students learn and process the problem so that it becomes meaningful. What is meant by the acquisition is the result of student learning obtained from experience and observation of the processed environment into a concept acquired by actively learning through process skills.

\subsection{The Importance of the Process Skills Approach}

There are several reasons underlying the need to apply a process skill approach (PKP) in teaching and learning activities, namely the development of science progresses faster so that teachers can not teach all the facts and concepts to students.

Psychologists generally argue that young people understand complicated and abstract concepts when it is accompanied by examples of congestion. The discovery of science is not relatively one hundred percent true, and the development of concepts is not released from the development of attitudes and values of students in the process of teaching and learning. According to Dimiyati (2002: 137), "Approach of process skills (PKP) needs to be applied in teaching and learning activities based on the following reasons: the acceleration of science and technology changes, emotional and physical intellectual experience is needed to obtain optimal learning outcomes, and the value of this perpetual quest of righteousness

\subsection{Pattern of Implementation of Process Skill Approach}

In implementing the process skill approach, it is necessary to pay attention to some things. They are a learning which must be appropriate with the 
curricular objectives; must hold on the rationale that all students have the ability (potential) according to their nature; should provide opportunities; awards and motivation for student to argue, think, and express their feelings and thoughts. The guidance for student must be based on the student's learning experience. It is necessary to make the coach lead to the student's ability to process his findings and must adhere to the principle of "Tut Wuri Handayani".

To implement the process skill approach in science learning, it must observe the fundamental skills of both mental, physical and social.

The meaning of basic skills are:

A) Observation

Activities of observation can be done by students through learning activities, noticing, listening, feeling, tasting and collecting information. Observing activities is the lowest level in the development of basic skills of learners, because it is only on the vision with the five senses. Basically observing and seeing are two different things, although at first glance it contains the same meaning. Seeing is not necessarily observed, because every day students may see a variety of plants, animals, other objects around it, but just see without observing how exactly the plant, the animal is growing.

B) Classifying

Classifying is a process skill for selecting various objects of events based on particular properties. Therefore, it is obtained a group or similar groups of objects in question. Classifying can be done by finding equations with equating, combining, classifying and grouping

C) Communicating

Communicate is not only through speaking but with pictures, writing and appearance. According to Djamarah in Ade Sanjaya (2000: 16), communicating activities can develop well in learners themselves if they perform activities such as: discussing, reciting, dramatizing, asking, composing, demonstrating, expressing and reporting in the form of oral, written, drawing and appearance

D) Measuring

Measurable means comparing measured with specified certain size units. Developing measuring skills can be applied by way of developing something, since basically a measure is comparing, for example, students compare their experimental IPA results.

\section{E) Predicting}

Predicting is the anticipation or prediction of something that will happen in the future, based on a pattern of certain tendencies, or the relationship between facts and concepts in science. students can develop predicting skills through anticipatory learning activities based on patterns/trends. The relationship between data and the relationship of information. It is similar with predicting the time of sunrise.

F) Summing

It is a skill to decide the state of an object or event based on known facts, concepts and principles. An example of the concluding activity is that based on observations it is known that the wax dies when placed on a bottle or glass in a closed state, then learners conclude that the wax will live or light up if there is oxygen

\subsection{The Steps on the Implementation of Process Skill Approach}

There are some steps taken in the approach of process skills in science learning. Firstly, introduction preliminary activities are intended to direct students on the subject matter so that they are ready to follow teaching and learning activities, both mentally, emotionally and physically. This preliminary activity is carried out by the repetition of materials or materials that have been experienced by learners who have relevance or relationship with the material or materials to be taught. Next, by arousing and directing the attention of learners by asking questions, opinions and suggestions, showing images related to the material.

The next step, focus on core activity is to explain the subject matter followed by demonstrations, pictures and capital. The purpose of this activity is to develop the ability to observe quickly, carefully and precisely. Activities classified in the learning process steps or core areas characterized by process skills include: formulating observations by detailing; classifying subject matter absorbed from observation activities; interpreting grouping results by showing the nature; things and events or the symptoms contained in each group, forecasting the cause of events or other that may occur at other times or receive a different treatment, applying the attitude skills knowledge gained from previous activities on new or different events, planning research, and communicating results of activities on others with discussions, lectures and others.

The teacher initiates the activity by raising the process skill problem. If the student's material knowledge is not sufficient to answer the problem, then the teacher guides the student towards the correct answer or explains the material that the student has not understood. Teachers give assignment to students around. Then the teacher gives follow-up questions and encourages students to draw conclusions from various answers, to the correct conclusions. Teachers always monitor students' learning, to find out whether the desired 
material is understood, students are given the opportunity to ask questions and ask for teacher explanation.

Lastly, in the closing activity can be done by reviewing teaching and learning activities that have been implemented and conclude the results that have been obtained. Moreover, it also conduct a final test to find out how deeply the students capture the delivered material as well as give tasks such as PR.

\section{CONCLUSIONS}

The approach of process skill is the teachinglearning approach that leads to the development of basic physical and social skills to find facts and concepts. In other words, it means that development of attitudes and values through the teaching-learning process that has enabled the students to be able to grow a certain number of skills in the learners. To implement the process skill approach in science learning, it must observe the fundamental skills of: observation, classifying, communicating, measuring, predicting and concluding. There are some steps taken in this approach such as introduction to direct students on the subject matter so that they are ready to follow teaching and learning activities, both mentally, emotionally and physically. Then, the core activities describes the subject matter followed by demonstrations, demonstrations, pictures, capital. Lastly, the closure activities review teaching and learning activities that have been implemented and conclude the results that have been obtained.

\section{REFERENCES}

[1] Abidin, Muhammad Zainal. (2011). Pendekatan Keterampilan Proses. Diambil pada tanggal 18 Maret 2016, dari http://masbied.com

[2] Darmin, E. T. (2003). Belajar Dan Pembelajaran. Surabaya: Terbit Terang.

[3] Moradi M., Etemad S. Gh., Moheb A. (2010). Synthesis of Magnetic Polyvinyl Alcohol

[4] Sanjaya, Ade. (2011). Pendekatan Keterampilan Proses.Diambil pada tanggal 19 Maret 2016.

[5] Subroto, Suryo. (1996). Proses Belajar Mengajar Disekolah. Jakarta: Rineka Cipta.

[6] Sudjana. (1997). Penilaian Proses Belajar Mengajar. Bandung : PT. Remaja Rosda Karya. 